\title{
Online learning and its problems in the Covid-19 emergency period
}

\author{
Rimba Hamid *, Izlan Sentryo, Sakka Hasan \\ Universitas Halu Oleo. Jalan H.E.A. Mokodompit Kampus Hijau Bumi Tridharma, Kendari, 93232 Indonesia \\ * Corresponding Author. E-mail: rimbahamid@uho.ac.id
}

Received: 3 June 2020; Revised: 13 June 2020; Accepted: 18 June 2020

\begin{abstract}
This research aims to obtain an in-depth description about: (1) distribution of the students of PGSD FKIP UHO (Department of Elementary School Teacher Education, Faculty of Teacher Training and Education Sciences, Halu Oleo University) based on domicile in implementing online learning in the Covid-19 period; (2) infrastructure support for the effectiveness of online learning in the Covid-19 period; and (3) students' perceptions about online learning conducted by PGSD FKIP lecturers at UHO during the Covid-19 period. This research was conducted in May 2020, which was included in the descriptive study, by conducting a survey of PGSD FKIP UHO students who were scattered in all regencies / cities in Southeast Sulawesi and other regions. Data collection techniques were those using open and closed questionnaires, with 316 students of 2017, 2018 and 2019 classes who became the subjects and filled out questionnaires online from the links sent. Data obtained from students in the form of qualitative and quantitative raw data collected online and converted in Excel format. The data were then processed based on the focus of this study. Based on the results of the processed data, an in-depth descriptive quantitative and qualitative analysis was carried out. The results of the study showed that: (1) PGSD FKIP UHO students in the online learning process concentrated on 3 main regencies/cities, namely Kendari City, Muna Regency and Konawe Selatan Regency; (2) The main supporting factors for the effectiveness of online learning in the Covid-19 period were the carrying capacity of network access and the ability of devices to access the internet; (3) Students perceived that the implementation of online learning during the Covid-19 period has not been fully effective.
\end{abstract}

Keywords: learning, online, perception, effective

How to Cite: Hamid, R., Sentryo, I., \& Hasan, S. (2020). Online learning and its problems in the Covid-19 emergency period. Jurnal Prima Edukasia, 8(1), 86-95. doi:https://doi.org/10.21831/jpe.v8i1.32165

\section{Introduction}

The Corona Virus Disease (Covid-19) pandemic or plague has struck more than 200 countries in the world and has given its own challenges for educational institutions, especially higher education. Anticipating the transmission of the virus, the government has issued various policies, from isolation, social and physical distancing to Large-Scale Social Restrictions (PSBB). This condition requires citizens to stay at home, work, worship and study at home(Jamaluddin et al., 2020, p. 2)

In order to prevent the development and spread of Covid-19 within the education unit environment, the Ministry of Education and Culture (Kemdikbud) issued Circular Letter No. 3 of 2020 dated March 9, 2020 which contained 14 appeals or instructions. Covid-19 is a new viral infection that resulted in the infection of 90,308 people as of March 2, 2020. This virus began in Wuhan, China on December 31, 2019. The virus, which is a single positive RNA strain, infects the respiratory tract (Yuliana, 2020, p. 192).

The availability of literature on Covid-19 in relation to educational studies has not been very much. This is not because education is not directly affected by the effects of the Covid-19 epidemic but because studies in education rarely include the effects of disease on providing effective education for students around the world. The level of Covid-19 spread has rapidly made every sector of human life feel its effects immediately(Sintema, 2020, p. 1).

This condition forces educational institutions, including LPTK, to make breakthroughs related to learning methods and models that must be chosen so that learning continues even though it is done virtually (online) with all the consequences of limitations, including those of lecturers who do not yet 
fully have online learning skills, and those of students who have limited carrying capacity of existing infrastructure in their domicile.

In anticipation of all the possibilities in relation to the outbreak of the Covid-19 pandemic, in a report titled "A framework to guide an education response to the COVID-19 Pandemic of 2020" several checklists for the education response to the covid-19 pandemic are outlined, including: (a) identification of ways of delivering education. When feasible, it must include online learning, as it provides the greatest flexibility and opportunities for interaction. If not all students have devices and connectivity, find ways to provide them for the students. Explore partnerships with the private sectors and the community in securing the resources provided by these devices and connectivity; (b) clearly defines the role and expectations of the teacher to effectively direct and support students to learn in new situations, through direct instruction if possible or guidance for independent learning; (c) Create a website to communicate with teachers, students and parents about curriculum goals, suggested strategies and activities and additional resources (Cooper et al., 1996, p. 5; Reimers \& Schleicher, 2020).

However, in terms of assessment, if it refers to the 2013 Curriculum, it is very likely to be problematic because of the difficulty of conducting authentic assessments that refer to assessment standards, which consist of (1) attitude competency assessment through observation, self-assessment, peer assessment by students and journals, (2) knowledge through written tests, oral tests, and assignments, and (3) skills through performance appraisal, namely assessments that require students to demonstrate certain competencies using practice tests, products, projects, and portfolio(Maryati et al., 2019, p. 130).

On campus, along with the Covid-19 pandemic case, the learning that has been carried out using face-to-face or offline methods suddenly has to change to the online method. Based on UHO Rector Circular Letter Number 02/UN29/RT/2020 dated March 16, 2020 concerning Policy Formulation in Responding to the Corona Virus (Covid-19) Spread in the Halu Oleo University (UHO) Environment in point 2) it is confirmed that: "all teaching and learning activities (KBM) or face-to-face lectures are replaced by online learning methods by utilizing the online media available at UHO on the link http://egreen.uho.ac.id or other online media.

On the national level, issues Circular of Minister of Education and Culture No. 36962/MPK.A/ HK/2020 dated 17 March 2020 concerning Online Learning and Working from Home to Prevent the Spread of Covid-19 in point 4a emphasizes the implementation of online learning at home for students and students, and in point $4 \mathrm{~b}$ describes the process of teaching or lecturing from home through video conferencing, digital documents, and other online facilities from providers that have collaborated with Kemdikbud which are prepared free of charge (Menteri Pendidikan dan Kebudayaan Republik Indonesia, 2020). Learning facilities and the websites as stated in this Circular Letter can be seen in the following Table 1:

Table 1. Learning Facilities and Websites for Access Available for Free from Kemdikbud

\begin{tabular}{ll}
\hline \multicolumn{1}{c}{ Learning Facility } & \multicolumn{1}{c}{ Website } \\
\hline Learning House & https://belajar.kemdikbud.go.id \\
Google G Suite for Education & https://blog.google/outreach-intiative/education/offline-access-covid-19 \\
Smart Class & https://kelaspintar.id \\
Microsoft Office 365 & https://microsoft.com/id-id/education/products/office \\
Quipper School & https://quipper.com/id/school/teachers \\
Ruang Guru Online School & https://ruangguru.onelink.me/blPk/efe72b2e \\
Sekolahmu & https://sekolah.mu/tanpabatas \\
Zenius & https://zenius.net/belajar-mandiri \\
\hline
\end{tabular}

Based on the results of an evaluation by Kemdikbud, online learning conducted by lecturers and students runs quite effectively even though changes occur in a relatively short time. There were $33.51 \%$ of students who were able to understand online learning materials; $30.90 \%$ understand the material well; and $5.64 \%$ understand the material very well. The evaluation results also mentioned that as many as $25.34 \%$ of students stated that lecturers were able to deliver course material online; $45.56 \%$ of the lecturers delivered the lecture material well; and $15.84 \%$ of the lecturers delivered the lecture material very well (Seno, 2020).

In relation to the existing problems, especially on the problems faced by students in online learning during the Covid-19 pandemic, the main purpose of this research is to obtain an in-depth overview of: (1) distribution of PGSD FKIP UHO students based on domicile in carrying out online learning in 
Jurnal Prima Edukasia, 8 (1), 2020 - 88

Rimba Hamid, Izlan Sentryo, Sakka Hasan

the Covid-19 period; (2) infrastructure support for the effectiveness of online learning in the Covid-19 period; and (3) students' perceptions about online learning carried out by PGSD FKIP lecturers at UHO during the Covid-19 period.

\section{Method}

This research was carried out in May 2020, which was included in the descriptive study, by conducting a survey of PGSD FKIP UHO students who were scattered in all regencies/cities in Southeast Sulawesi and other regions. Data collection techniques were by using open and closed questionnaires, with the research subjects of 316 students of the 2017, 2018 and 2019 classes who filled out the questionnaire online from the link sent using Google Form. Survey research design is a procedure in quantitative research in which the researcher administers the survey to a sample or population of people to describe the attitudes, opinions, behaviors or special characteristics of the population (Creswell, 2015, p. 752).

With the increasing use of Websites and the Internet, Web-based questionnaires are becoming increasingly popular. Web-based questionnaire is a survey instrument to collect data available on the computer (Creswell, 2015). The steps taken in this research are: First, preparing the questionnaire instrument by using google form which will be used or data collection. The aspects contained in the questionnaire are: spread of students, supporting infrastructure, and student perceptions in online learning organized by lecturers during the Covid-19 period. Second, validating instruments with colleagues, (Head of Department) specifically with regard to content and construct validity.

The data obtained from students are in the form of qualitative and quantitative raw data collected online and converted in Excel format. The data are then processed based on the focus of this study. Based on the results of the processed data, an in-depth descriptive quantitative and qualitative analysis is carried out.

\section{Results and Discussion}

\section{Distribution of PGSD Students During Online Learning in the Covid-19 Period}

Online data collection is related to the distribution of 316 PGSD FKIP UHO students during the online learning process in Covid-19 period spread across 17 Regencies / Cities in Southeast Sulawesi plus other regions outside Southeast Sulawesi. Profile of the distribution of students at each location of domicile can be seen in the following Figure 1.

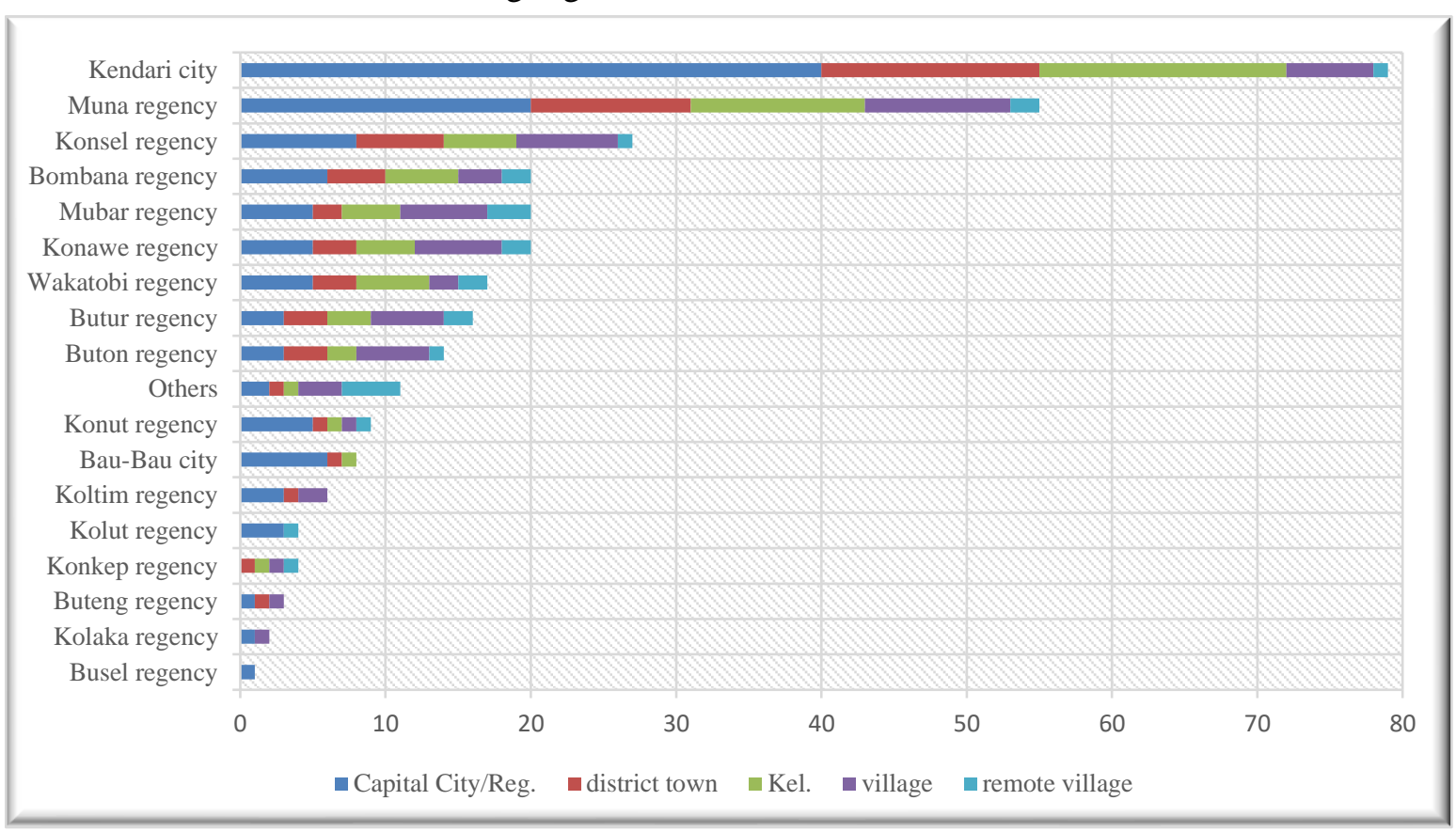

Figure 1. Distribution of the Number of PGSD Students Based on Domicile During Online Learning in the Covid-19 Period 
Based on the data in Figure 1, it can be seen that during the Covid-19 period, PGSD FKIP UHO students were concentrated in three main regions, namely in Kendari City (25\%), Muna Regency $(17.41 \%)$ and Konawe Selatan Regency (8.54\%). This data shows that some students consider to stay temporarily in Kendari during the online learning period because the internet network facilities are sufficient, not to mention during the Covid-19 emergency there are restrictions on human movement, although in Kendari the PSBB rules have not yet been applied. The mobility of students during online lectures or online assignments by lecturers forces them to find locations that allow them to be able to access an adequate network for online lectures, especially if the lecturers carry out lectures with virtual meetings, for example by using the application of Zoom Cluod Meeting or Google Meet.

This is known from the data of Lecturer Evaluation by Student (EDOM) for the even semester of 2019.2 lectures that almost all lecturers carried out online lectures by holding virtual meetings and facilitating student assignments with online classes with the Google Classroom and Edmodo applications, but what's interesting about the findings of the survey results on the implementation of online lectures by PGSD FKIP UHO lecturers by students is that lecturers have carried out online lectures by giving assignments online but rarely return them to students. This is supported by the fact that there are still lecturers who only use supporting facilities such as email, WhatsApp or by SMS in accordance with the level of information technology capabilities they have, and of course it will complicate and make the online learning process less effective.

\section{Supporting Infrastructure for the PGSD Students' Online Learning}

The success of online learning cannot be separated from the availability of supporting learning infrastructure such as: the availability of stable internet access, access devices with the latest technology, devices used for internet access, as well as the presence of students who live in areas where there is no electricity network, so that practical online learning very difficult to implement. Infrastructure carrying capacity data for online learning effectiveness for FKIP UHO PGSD students with the above-mentioned variables are summarized in the graphical picture in Figure 2.

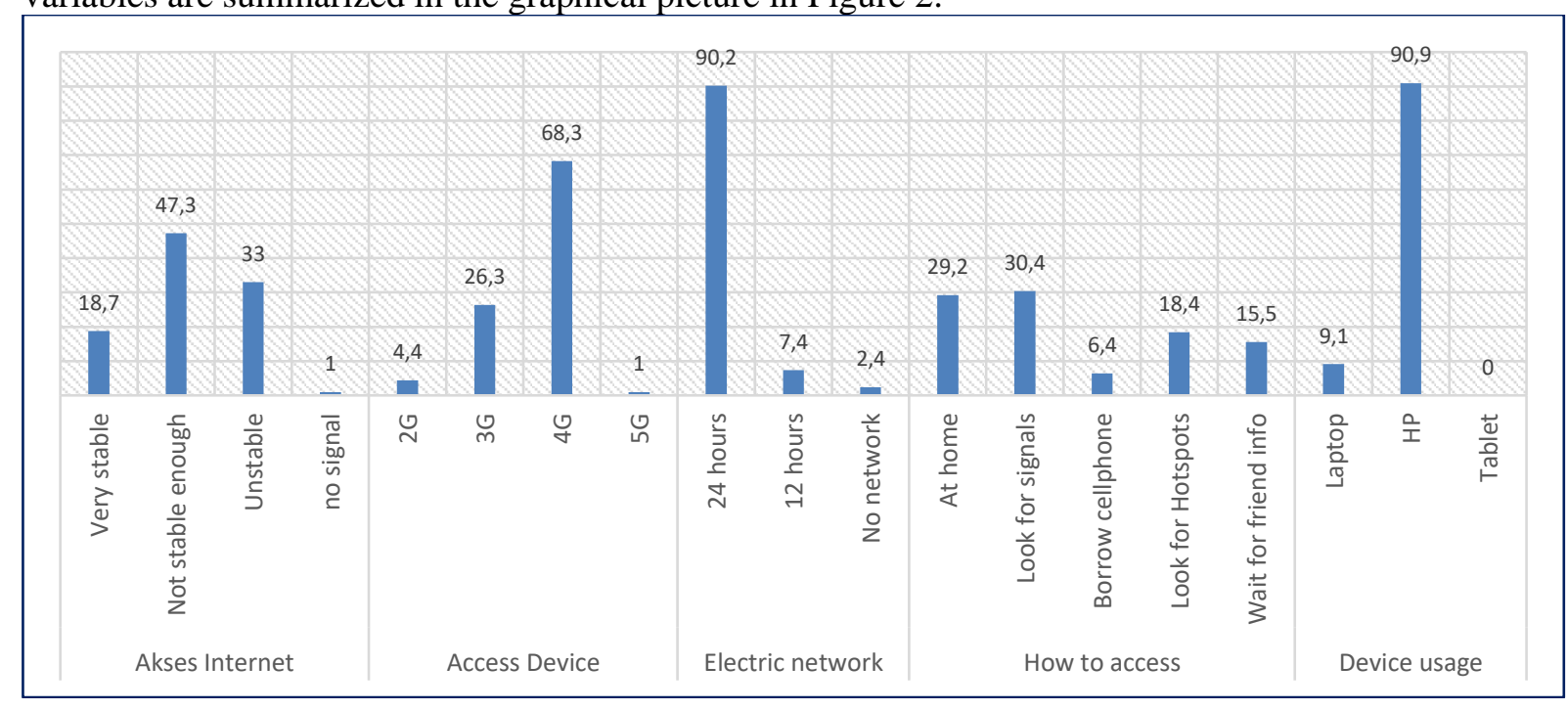

Figure 2. Profile of Supporting Capacity (\%) of PGSD FKIP UHO Students' Online Learning

Based on the data in Figure 2 it appears that in general (81.3\%) PGSD students access the internet with a less stable to unstable carrying capacity. This is the main complaint of students in online learning during the Covid-19 period. This fact is reinforced by the data that only $29.2 \%$ of students access the internet at their homes to study and complete assignments online from lecturers, while $30.4 \%$ of students look for areas with strong signals to access the internet, in fact there are still $18.4 \%$ of students (generally those in cities) who access the internet by searching for available hotspots. The saddest condition was that there were still as many as $15.5 \%$ of students who were just waiting for information from other students who have first obtained information, especially online assignments from lecturers.

Another condition that contributed to the ineffectiveness of online learning during the Covid-19 pandemic was that almost all students (90.9\%) accessed the internet in online learning using mobile phones, where the internet is closely related to public computer networks throughout the world. The 
Jurnal Prima Edukasia, 8 (1), 2020 - 90

Rimba Hamid, Izlan Sentryo, Sakka Hasan

internet provides access to a number of communication services including World Wide Web and carries emails, news, entertainment and data file (Badan Pusat Statistik Provinsi Sulawesi Tenggara, 2019, p. 359). In relation to accessing and storing data by using cell phones in learning, there is a practical side and speed of access, but on the other hand there are also shortcomings because in general data related to lectures are generally stored on student laptops, so there are relatively obstacles to access them. The data in Figure 2 also shows that only a small percentage (9.1\%) of students use laptops while studying online, so the speed of doing their assignments has a delay time,

so these factors contribute to the number of student complaints related to the accumulation of lecturer assignments at the same relative time. This condition certainly requires adaptation for students in preparing themselves for future online lectures, although this obstacle cannot be separated from the carrying capacity of internet network infrastructure in the area of student domicile in online learning.

It cannot be denied that in terms of access, the challenge for the government is when Distance Learning (PJJ) is conducted online and implemented in areas where accessibility, infrastructure and digital literacy are still low. Based on the results of the 2018 APJII National Internet User Penetration survey, the distribution of data shows that more than half of internet users in Indonesia are in the Java region $(55.7 \%)$, followed by Sumatra (21.6\%), Sulawesi-Maluku-Papua (10.9\%), Kalimantan (6.6\%), and Bali and Nusa Tenggara 5.2\% (bebas.kompas.id, 30 March 2020). One of the difficulties encountered in the process of learning from home is the limitations of the internet both from the availability of networks and credit balance to access online learning (Arifa, 2020, p. 16).

The above-mentioned facts will also contribute to the effectiveness of online learning in terms of ease of internet access for students who are located or domiciled in locations that are not covered by the internet network. As an illustration, the following is a rural village / urban village profile according to the existence of Base Transceiver Station (BTS), Cellular Telephone Signal, and GSM or CDMA Internet Signal in Southeast Sulawesi (Badan Pusat Statistik Provinsi Sulawesi Tenggara, 2019)

Table 2. Number of Rural Villages/Urban Villages According to the Existence of Base Transceiver Station (BTS), Cellular Telephone Signal, And GSM or CDMA Internet Signal, 2018

\begin{tabular}{|c|c|c|c|c|c|c|c|c|c|c|}
\hline \multirow[b]{2}{*}{ Regency/City } & \multicolumn{2}{|c|}{ BTS availability } & \multicolumn{4}{|c|}{ HP signal strength } & \multicolumn{4}{|c|}{ GSM or CDMA internet signal } \\
\hline & Available & NA & $\begin{array}{l}\text { Very } \\
\text { Strong }\end{array}$ & Strong & weak & NA & 4G/LTE & $3 \mathrm{G} / \mathrm{H} / \mathrm{H}+$ & 2G/GPRS & NA \\
\hline Buton & 27 & 68 & 22 & 34 & 28 & 11 & 10 & 31 & 33 & 10 \\
\hline Muna & 41 & 145 & 39 & 98 & 45 & 4 & 39 & 113 & 12 & 18 \\
\hline Konawe & 49 & 322 & 64 & 208 & 69 & 30 & 128 & 177 & 24 & 12 \\
\hline Kolaka & 39 & 96 & 33 & 79 & 21 & 2 & 55 & 61 & 8 & 9 \\
\hline Konawe Selatan & 64 & 293 & 47 & 166 & 134 & 10 & 84 & 222 & 23 & 18 \\
\hline Bombana & 32 & 111 & 23 & 46 & 53 & 21 & 36 & 41 & 18 & 27 \\
\hline Wakatobi & 24 & 76 & 10 & 69 & 20 & 1 & 33 & 47 & 12 & 7 \\
\hline Kolaka Utara & 29 & 104 & 10 & 72 & 46 & 5 & 24 & 84 & 15 & 5 \\
\hline Buton Utara & 8 & 83 & 12 & 30 & 45 & 4 & 24 & 44 & 4 & 15 \\
\hline Konawe Utara & 9 & 164 & 12 & 63 & 73 & 25 & 29 & 65 & 6 & 48 \\
\hline Kolaka Timur & 18 & 115 & 20 & 46 & 42 & 25 & 38 & 44 & 15 & 11 \\
\hline Konkep & 13 & 83 & 10 & 19 & 44 & 23 & 13 & 8 & 8 & 44 \\
\hline Muna Barat & 15 & 71 & 12 & 35 & 39 & 0 & 17 & 32 & 31 & 6 \\
\hline Buton Tengah & 23 & 54 & 9 & 29 & 38 & 1 & 14 & 39 & 23 & 0 \\
\hline Buton Selatan & 14 & 56 & 27 & 23 & 19 & 1 & 33 & 29 & 1 & 6 \\
\hline Kota Kendari & 49 & 16 & 40 & 22 & 3 & 0 & 48 & 14 & 1 & 2 \\
\hline Bau-Bau & 24 & 19 & 8 & 29 & 6 & 0 & 26 & 17 & 0 & 0 \\
\hline $\begin{array}{l}\text { Southeast } \\
\text { Sulawesi }\end{array}$ & 478 & 1876 & 398 & 1068 & 725 & 163 & 651 & 1068 & 234 & 238 \\
\hline Source: village $\mathrm{p}$ & ntial data & ollecti & 2018 & & & & & & & \\
\hline
\end{tabular}

In connection with the following access constraints included excerpts of comments from 3 students related to online learning during the Covid-19 period: (1) "The constraints faced while studying online: (a) network problems, especially in my area if the electrical power fails and internet network sometimes also turns off, (b) costs, the campus should provide the least cost to help ease the burden on students; (c) "My constraints are First, related to the problem of network instability both from myself and the lecturer, sometimes the delivery of the material makes me late or do not attend the lecture. Second, wasteful internet data packages, I say that because the courses I am facing are not just one or 
Jurnal Prima Edukasia, 8 (1), 2020 - 91

Rimba Hamid, Izlan Sentryo, Sakka Hasan

two courses but 10 courses. Third, I do not understand the material that has been given. My suggestion is that the method used should not be too burdensome, troublesome or it would be nice if large tasks are done in groups;(2) We suggest that during the online learning process the lecturer gives the right time and not suddenly when going to do online lectures, and also when giving an online assignment students are given enough time to work on it, because there are also many student assignments from other courses so the assignment cannot be completed quickly because there are still tasks waiting to be done because of the short processing time" (Source: PGSD students' written responses online by using google form).

Nevertheless, these constraints are a record of improvement as part of good reflection in the future. This of course can be minimized by better preparing for online learning by lecturers who have limited ability to organize online classes, for example using the google classroom application, storing data on an online drive, for example by using Google Drive, OneDrive and Dropbox. Also, students must improve their skills in following the online learning process both independently and in groups, and also be better able to adapt to the advancement of information technology, even with the support of infrastructure that is not yet optimal.

\section{PGSD Students' Perceptions on Online Learning with Lecturers}

The Covid-19 pandemic had a very significant impact on the educational aspect. This was confirmed by Listiana (2020, p. 5) in an International Webinar Conference held by FKIP UM Surabaya on May 20, 2020 that the impacts are: (a) Changing learning system from face-to-face learning conducted as usual to a distance learning system (online); (b) Learning from offline to online cannot necessarily be carried out effectively; (c) Online learning tools still lack support; (d) Adaptation of students in the use of online media; (e) Network access, additional costs for students; and (f) The competence of lecturers needs to be prepared in designing online-based learning.

The impact has implications for the readiness of lecturers and students in carrying out online or distance learning which is of course very different from the readiness of face-to-face learning. As explained in the "Distance Learning Guide Learning at Home C-19" that there are three main tasks in designing and implementing distance learning, namely: (1) WHAT (Learning content); (2) WHO (learning profile, current conditions and needs); and (3) HOW (learning design and implementation) (Direktorat Jenderal Guru dan Tenaga Kependidikan, 2020, pp. 7-19).

When the teacher or lecturer makes a shift from face to face learning to distance learning, then the fundamental thing is how the lecturer needs to adjust the strategy and material. One important factor to consider is what resources are available to lecturers and students involved in online learning, where online learning is an established learning paradigm that has a theoretical and practical appeal (ShalevShwartz, 2011, p. 108).

Still related to the contents of the guide, it is explained that what needs to be considered by lecturers in implementing online learning are: (1) Ensuring the technology, platforms, equipment and resources available to lecturers and students-print, audio and radio, video and TV, computer-based, Internet based and telephone based. The considerations are: (a) Which of these resources can be used by all or most students and which are the easiest to use for communication, direct instruction, discussion, job sharing and assessment? and (b) Which of the students does not have access to telephone, computer, internet? (2) Ensuring teaching and learning material that can be adapted for distance learning. Look for educational resources that can be freely accessed and ensure these quality resources.

In the context of face-to-face learning, interaction between lecturers and students is an important key. Therefore, in online learning not only is the readiness of the lecturers, but other factors that cannot be ruled out are how students perceive the online learning itself, which they all must suddenly act on in the Covid-19 period. The description of students' perspective on online learning held by PGSD lecturers can be seen in Figure 3.

From the data presented in Figure 3, it appears that students' perceptional problems in carrying out online learning in the Covid-19 period vary. Of the five variables perceived based on the real conditions of what is experienced by students, the findings that need enough attention from all parties are about the $74.2 \%$ of students who accumulatively perceive that online learning is less effective and ineffective. This is in line with the large number of students (64.3\%) who feel less satisfied and dissatisfied with online learning in the Covid-19 period. Of course many factors affect this perception, especially on the limitations of optimizing the potential, both from students and from lecturers. Even from the data it also appears that the values of academic subjectivity will emerge because of the large 
Jurnal Prima Edukasia, 8 (1), 2020 - 92

Rimba Hamid, Izlan Sentryo, Sakka Hasan

number of students $(66.2 \%)$ who sometimes and always copy-paste in carrying out online assignments from lecturers. The limited space for interaction between students and lecturers in online learning decreases the interest of students in participating in learning, and there are even some students stating that they lack understanding of lecture material that is not explained directly by the lecturer face to face. The factor of learning difficulties online is very possible if done synchronously, for example by using virtual meeting applications such as: Google Meet, Zoom Cloud Meeting, or Microsoft Teams. This can occur because it requires students to make adequate preparations including internet access. On the other hand, lecturers can actually use more flexible alternatives with asynchronous online learning, for example through supporting applications such as online classes, WhatsApp, or uploading assignments in the form of video analysis or learning content uploaded on their lecturers' You Tube Channel. To facilitate all of these activities, of course it takes the ability of lecturers or teachers to design learning content in an attractive multimedia form (Primamukti \& Farozin, 2018; Sharma, 2013).

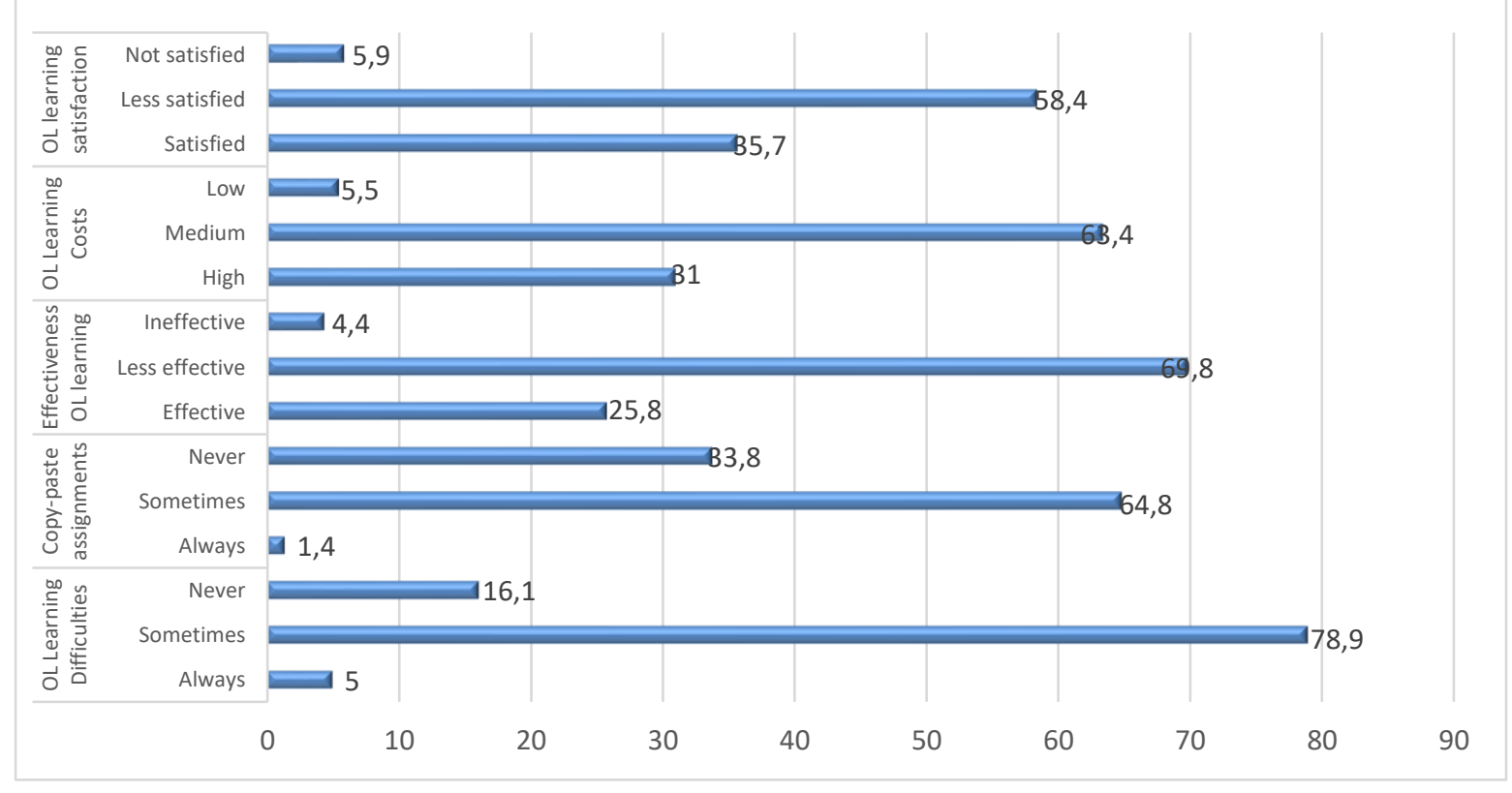

Figure 3. Spread of Students' Responses (\%) in Perceiving Online Learning with Lecturers

The lecturer or teacher helps carry out virtual discussions among students, provides homework, and follows up with students individually. Sometimes these lessons are synchronous (all teachers and students meet at the same time) and sometimes asynchronous (not simultaneously). In both cases, the lecturer or teacher should provide an opportunity for students or students to be seriously involved with the subject matter, and students or learners, in many cases, are asked to interact with each other virtually (Loeb, 2020).

This is in line with the statement of the Secretary General of the Federation of Indonesian Teachers' Union Heru Purnomo who states that so far many schools, especially in Jakarta, have applied the online assignment method to students. The assignment is carried out through various available social media, especially WhatsApp groups. He considers, in an emergency due to the corona virus as it is now, it is the form of assignment that is seen to be effective in distance learning. Consequently, the introduction of the concept of a lesson as applied in face-to-face learning cannot work well (Ashari, 2020).

The fact that is in line with the results of this study is the statement made by the Commissioner of KPAI about problems of Distance Learning (PJJ) that online PJJ is not optimal when the majority of teachers are not accustomed to applying online learning in the learning process before the covid-19 pandemic. The results of the teacher survey show that teachers who are already accustomed to using online learning (digital-based) continuously in the classroom are only (8\%). There are even teachers who have never carried out online learning before this crisis $(9.6 \%)$. Online PJJ is not optimal when the majority of teachers are not accustomed to applying online learning in the learning process before the covid-19 pandemic. The results of the teacher survey show that teachers who are already accustomed to using online learning (digital-based) continuously in the classroom are only (8\%). There are even teachers who have never carried out online learning before this crisis (9.6\%) (Winahyu, 2020). 
Distance education is a teaching technique that makes students and instructors physically separated or separated by time. Usually students use various types of material, such as electronic media, references, books and CD-ROMs. Instead of face-to-face learning, this material and content is basically instructed by technology (Abuhassna \& Yahaya, 2018, p. 3050).

This phenomenon is very likely related to the results of research by Nakayama et al. (2007, p. 1) which shows that student characteristics have an effect on learning experiences and learning performance. These results indicate that understanding the benefits of e-learning and student characteristics, as well as knowing how learning with e-learning content can provide an important key to promoting student success in online learning.

In line with the above reality, the results of research Hikmat et al. $(2020$, p. 1) show that learning online with Zoom and WhatsApp is only effective for theoretical and practicum subjects, whereas in practice courses and online course subjects are less effective.

Slightly different from the results of research conducted by Saifuddin (2018, p. 108) before the Covid-19 pandemic showed that students have a good perception of e-learning, this is influenced by the knowledge and experience of students in using e-learning. Students showed their willingness to do learning with e-learning by $86.3 \%$, besides that students supported the e-learning content where there were instructional materials that had to be done with e-learning, a picture of learning that would be done in class, as well as material that could be learned before learning face to face. The level of student satisfaction in using e-learning reaches $77 \%$. The need to develop learning by combining e-learning with learning models and teaching materials that are in accordance with the characteristics of the material, so that the use of e-learning can be more maximized and provide provision to students when working as a teacher in the digital age.

According to a recent survey from the Babson Survey Research Group, more than 30 percent of college students in the United States take at least one distance course. Online education is a reasonable choice either you are a teenager or an adult. For you as a student, this can be a useful learning method to hone your skills in difficult subjects, or learn new skills (Josep, 2020). One of the factors is its flexibility, where online learning allows teachers and students to set their own pace of learning, and there is additional flexibility in organizing schedules that fit everyone's agenda. As a result, using an online education platform allows a better work balance and study, so there is no need to give up. Studying online teaches you vital time management skills, which make finding good work-study balance easier. Having a shared agenda between students and teachers can also encourage both parties to accept new responsibilities and have more autonomy.

The data in Figure 3 also shows that the level of student dissatisfaction with online learning during the covid-19 period was relatively high $(58.4 \%)$. Of course many factors influence, including the readiness of lecturers in carrying out learning, because so far they generally still use face-to-face learning directly. Basically, if online learning is well prepared, especially the content of teaching material, it will attract students to be involved in it. This is supported by research results from Ali et al. (2011, p. 123) which show that the majority of students on campus have a high level of satisfaction with studentlecturer interaction, lecturer performance and learning evaluation, this is not much different from what occurs in traditional learning where sufficient interaction occurs between students and their lecturers, renewable learning and designed with good, dedicated teacher, motivated and equipped with the necessary skills and knowledge.

One reason for the popularity of online learning is that it allows learning to occur under the control of students, whenever and wherever. Online learning also promises to promote justice by giving students access to learning that might not be available, such as accelerated courses in remote rural areas. By keeping in mind the diversity of students and geographical boundaries, online learning can provide professional support to schools for all students. Experienced teachers can teach in individual environments and can meet the special needs of gifted students and students who are trying to learn (Dichev et al., 2013, p. 92)

From various perspectives of online learning in the Covid-19 period it should not make our intention fade to organize better learning in the future, of course with improvements from many aspects that are still lacking because this is the initial stage of an offline learning revolution towards on line.

Therefore there is the need for more precise formulations in overcoming it all, for example, starting from issuing a policy of providing financial assistance (money) to each student to buy internet credit balance, or by replacing online lectures with other learning that is easy to implement for those 
Jurnal Prima Edukasia, 8 (1), 2020 - 94

Rimba Hamid, Izlan Sentryo, Sakka Hasan

who have difficulty accessing the internet. I think there are many options to deal with this, for the sake of creating effective learning that can run optimally.

\section{Conclusion}

Based on data analysis and the findings of this study it can be concluded that: (1) PGSD FKIP UHO students in the virtual learning process are concentrated in 3 main regencies/cities, namely Kendari City, Muna Regency and Konawe Selatan Regency; (2) The main supporting factors of the effectiveness of virtual learning in the Covid-19 period are the carrying capacity of network access and the ability of devices to access the internet; (3) Students perceive that the implementation of virtual learning in the Covid-19 period has not been fully effective.

\section{Reference}

Abuhassna, H., \& Yahaya, N. (2018). Students' utilization of distance learning through an interventional online module based on moore transactional distance theory. EURASIA Journal of Mathematics, Science and Technology Education, 14(7), 3043-3052. https://doi.org/10.29333/ejmste/91606

Ali, A., Ramay, M. I., \& Shahzad, M. (2011). Key factors for determining student satisfaction in distance learning courses: A study of Allama Iqbal Open University (AIOU) Islamabad, Pakistan. Turkish Online Journal of Distance Education, 12(2), 114-127. https://doi.org/10.17718/tojde.10766

Arifa, F. N. (2020). Tantangan pelaksanaan kebijakan belajar dari rumah dalam masa darurat Covid-19. Info Singkat: Kajian Singkat Terhadap Isu Aktual Dan Strategis, XII(7/I), 6.

Ashari, M. (2020). Proses pembejalaran daring di tengah antisipasi penyebaran virus corona dinilai belum maksimal. Pikiran Rakyat. https://www.pikiran-rakyat.com/pendidikan/pr01353818/proses-pembejalaran-daring-di-tengah-antisipasi-penyebaran-virus-corona-dinilaibelum-maksimal

Badan Pusat Statistik Provinsi Sulawesi Tenggara. (2019). Provinsi Sulawesi Tenggara dalam angka 2019. CV. Metro Graphia Kendari.

Cooper, H., Nye, B., Charlton, K., Lindsay, J., \& Greathouse, S. (1996). The effects of summer vacation on achievement test scores: A narrative and meta-analytic review. Review of Educational Research, 66(3), 227-268. https://doi.org/10.3102/00346543066003227

Creswell, J. (2015). Riset pendidikan, perencanaan, pelaksanaan dan evaluasi riset kualitatif dan kuantitatif $(\mathrm{V})$. Pustaka Belajar.

Dichev, C., Dicheva, D., Agre, G., \& Angelova, G. (2013). Current practices, trends and challenges in K-12 online learning. Cybernetics and Information Technologies, 13(3), 91-110. https://doi.org/10.2478/cait-2013-0028

Direktorat Jenderal Guru dan Tenaga Kependidikan. (2020). Panduan pembelajaran jarak jauh: Bagi guru selama sekolah tutup dan pandemi Covid-19 dengan semangat merdeka belajar. Direktorat Jenderal Guru dan Tenaga Kependidikan Kementerian Pendidikan dan Kebudayaan. http://repositori.kemdikbud.go.id/18501/

Hikmat, H., Hermawan, E., Aldim, A., \& Irwandi, I. (2020). Efektivitas pembelajaran daring selama masa pandemi Covid-19: Sebuah survey online. http://digilib.uinsgd.ac.id/30625/

Jamaluddin, D., Ratnasih, T., Gunawan, H., \& Paujiah, E. (2020). Pembelajaran daring masa pandemik Covid-19 pada calon guru: Hambatan, solusi dan proyeksi. In Karya Tulis Ilmiah UIN Sunan Gunung Djati Bandung. http://digilib.uinsgd.ac.id/30518/

Josep, G. (2020). 5 alasan mengapa pembelajaran online adalah masa depan pendidikan. Educations.Com. https://id.educations.com/articles-and-advice/5-reasons-online-learning-isfuture-of-education-17146

Listiana, L. (2020). Transformasi pembelajaran di masa pandemi Covid-19.

Loeb, S. (2020). How effective is online learning? What the research does and doesn't tell us. Education Week. https://www.edweek.org/ew/articles/2020/03/23/how-effective-is-online-learning-whatthe.html

Maryati, M., Zubaidah, E., \& Mustadi, A. (2019). A content analysis study of cientific approach and Copyright (C) 2020, Jurnal Prima Edukasia, ISSN 2338-4743 (print), ISSN 2460-9927 (online) 
authentic assessment in the textbook of curriculum 2013. Jurnal Prima Edukasia, 7(2), 128-138. https://doi.org/10.21831/jpe.v7i2.26792

Menteri Pendidikan dan Kebudayaan Republik Indonesia. (2020). Surat Edaran Nomor 3636Z/MPK.A/HK/2020 tentang pembelajaran secara daring dan bekerja dari rumah dalam rangka pencegahan penyebaran Corona Virus Disease (COVID-19). Kementerian Pendidikan dan Kebudayaan Republik Indonesia.

Nakayama, M., Yamamoto, H., \& Santiago, R. (2007). The impact of learner characteristics on learning performance in hybrid courses among Japanese students. The Electronic Journal of E-Learning, 5(3), 195-206.

Primamukti, A. D., \& Farozin, M. (2018). Utilization of interactive multimedia to improve learning interest and learning achievement of child. Jurnal Prima Edukasia, 6(2), 111-117. https://doi.org/10.21831/jpe.v6i2.19183

Reimers, F. M., \& Schleicher, A. (2020). A framework to guide an education response to the COVID19 Pandemic of 2020. Organisation for Economic Co-operation and Development.

Saifuddin, M. F. (2018). E-learning dalam persepsi mahasiswa. Jurnal VARIDIKA, 29(2), 102-109. https://doi.org/10.23917/varidika.v29i2.5637

Seno. (2020). Revolusi pendidikan tinggi di tengah pandemi Covid-19. Media Indonesia.Com. https://mediaindonesia.com/read/detail/313911-revolusi-pendidikan-tinggi-di-tengah-pandemicovid-19

Shalev-Shwartz, S. (2011). Online learning and online convex optimization. Foundations and Trends ${ }^{\circledR}$ in Machine Learning, 4(2), 107-194. https://doi.org/10.1561/2200000018

Sharma, P. (2013). Role of interactive multimedia for enhancing students' achievement and retention. International Women Online Journal of Distance Education, 2(3), 12-22.

Sintema, E. J. (2020). Effect of COVID-19 on the performance of grade 12 students: implications for STEM education. Eurasia Journal of Mathematics, Science and Technology Education, 16(7), 16. https://doi.org/10.29333/ejmste/7893

Winahyu, A. I. (2020). Komisioner KPAI bongkar permasalahan pembelajaran jarak jauh. Media Indonesia.Com. https://mediaindonesia.com/read/detail/309647-komisioner-kpai-bongkarpermasalahan-pembelajaran-jarak-jauh

Yuliana, Y. (2020). Corona virus diseases (Covid-19): Sebuah tinjauan literatur. Wellness And Healthy Magazine, 2(1), 187-192. https://wellness.journalpress.id/wellness/article/view/21026 